\title{
Peningkatan kemampuan guru dalam menyusun kelengkapan mengajar melalui in-house training
}

\author{
Maidarni Maidarni *) \\ Sekolah Dasar Negeri 03 Pasar Amping Parak
}

\begin{tabular}{l}
\hline Article Info \\
\hline Article history: \\
Received April $11^{\text {th }}, 2021$ \\
Revised May $09^{\text {th }}, 2021$ \\
Accepted Jun $13^{\text {th }}, 2021$ \\
\hline
\end{tabular}

\section{Keyword:}

Kemampuan guru

Kelengkapan mengajar In-House training

\begin{abstract}
Penelitian dilakukan di UPT SDN 03 Pasar Amping Parak Kecamatan Sutera selama kurang lebih dua bulan dimulai tanggal 3 Februari sampai dengan tanggal 4 Meret tahun 2020. Pengumpulan data dilakukan melalui angket, observasi dan dokumentasi. Dari angket diperoleh hasil bahwa secara keseluruhan Guru UPT SDN 03 Pasar Amping Parak Kecamatan Sutera menyatakan penting untuk memiliki kelengkapan mengajar. Sebagian besar Guru UPT SDN 03 Pasar Amping Parak Kecamatan Sutera merasa bahwa pengalaman mengajarnya masih minim pada mata pelajaran yang diajarkan, latar belakang pendidikan tidak begitu sesuai dengan mata pelajaran yang diajarkan dan pengetahuan tentang penyusunan kelengkapan mengajar masih kurang. Seluruh Guru UPT SDN 03 Pasar Amping Parak Kecamatan Sutera menghendaki adanya In-House Training penyusunan kelengkapan mengajar dan $100 \%$ Guru memiliki motivasi yang tinggi untuk mengikuti In-House Training dan memiliki keinginan yang kuat untuk membuat kelengkapan mengajar dan akan menggunakan kelengkapan mengajar tersebut sebagai penunjang proses pembelajaran. Penelitian dilakukan sebanyak 2 siklus. Pada siklus 1 diperoleh $42,5 \%$ Guru berhasil menyelesaikan penyusunan kelengkapan mengajar dan pada Siklus 2 terdapat 95\% Guru berhasil menyelesaikan penyusunan kelengkapan mengajar. Jadi ada peningkatan kemampuan Guru dalam menyusun kelengkapan mengajar setelah dilakukan In-House Training tahap 1 dan masingmasing Guru menunjukkan peningkatan yang signifikan. In-House Training adalah salah satu pola yang sangat efektip untuk meningkatkan kemampuan Guru dalam menyusun kelengkapan mengajar.
\end{abstract}

(C) 2021 The Authors. Published by IICET

This is an open access article under the CC BY-NC-SA license

(https://creativecommons.org/licenses/by-nc-sa/4.0)

\section{Corresponding Author:}

Maidarni Maidarni,

Sekolah Dasar Negeri 03 Pasar Amping Parak

Email: maidarni@gmail.com

\section{Pendahuluan}

Untuk mewujudkan guru yang profesional sehingga mampu meningkatkan kompetensi dan mutu Guru yang bersangkutan, maka UPT SDN 03 Pasar Amping Parak Kecamatan Sutera merancang program program dan 
kegiatan yang mengarah pada peningkatan mutu Guru misalnya dengan mengikutsertakan Guru dalam pelatihan-pelatihan dan salah satunya melalui In-House Training penyusunan kelengkapan mengajar. Hal ini mendesak dilakukan karena dari angket yang diberikan kepada guru untuk mengetahui respon Guru terhadap pentingnya memiliki kelengkapan mengajar $57,4 \%$ menyatakan sangat setuju dan $42,6 \%$ setuju artinya seluruh Guru menyatakan setuju/sepakat untuk memiliki kelengkapan mengajar.

Selanjutnya dari angket juga terungkap bahwa pengalaman mengajar, ketidaksesuaian latar belakang pendidikan dan kurangnya pengetahuan tentang penyusunan kelengkapan mengajar menyatakan bahwa $48 \%$ sangat setuju, 33\% setuju 66\% cukup setuju itu artinya bahwa sebagian besar Guru merasa bahwa pengalaman mengajarnya masih minim pada mata pelajaran yang diajarkan, latar belakang pendidikan tidak begitu sesuai dengan mata pelajaran yang diajarkan dan pengetahuan tentang penyusunan kelengkapan mengajar masih kurang.

Lebih lanjut dari angket juga terungkap tentang perlunya diadakan In-House Training dengan data hanya $18 \%$ tidak setuju yang mengindikasikan bahwa hampir seluruh Guru menghendaki adanya In-House Training penyusunan kelengkapan mengajar.

Selain itu angket juga mengungkap bahwa Guru memiliki kemauan yang kuat untuk memiliki kelengkapan mengajar dengan data 33\% menjawab sangat setuju dan $66 \%$ menjawab setuju yang artinya seluruh Guru menyatakan jika diadakan In-House Training maka mereka akan mengikuti dengan sungguh-sungguh dan akan mengaplikasikannya dalam kegiatan pembelajaran.

Berdasarkan fenomenas di atas maka UPT SDN 03 Pasar Amping Parak Kecamatan Sutera menyatakan sangat perlu mengadakan In-House Training. Dengan adanya kegiatan In-House Training penyusunan kelengkapan mengajar diharapkan semua guru memiliki kelengkapan mengajar yang lengkap dan mengaplikasikannya dalam proses pembelajaran sehingga proses pembelajaran yang dilakukan akan lebih terarah karena tujuan pembelajaran, materi yang akan diajarkan, metode dan penilaian yang akan digunakan telah direncanakan dengan berbagai pertimbangan.

\section{Metode}

Penelitian Tindakan Sekolah ini dilakukan selama dua bulan yang dimulai dari tanggal 3 Februari sampai dengan tanggal 4 Meret tahun 2020 . Pada siklus 1 terbagi menjadi empat tahap yaitu tahap persiapan, tahap pelaksanaan tindakan (Inhouse-training Tahap 1), tahap pengumpulan data tahap analisis data (refleksi). Penelitian dilakukan di UPT SDN 03 Pasar Amping Parak Kecamatan Sutera.

Penelitian tindakan sekolah ini dilakukan oleh peneliti sendiri Maidarni selaku kepala sekolah pada UPT SDN 03 Pasar Amping Parak Kecamatan Sutera.

Tabel 1. Rencana Tindakan

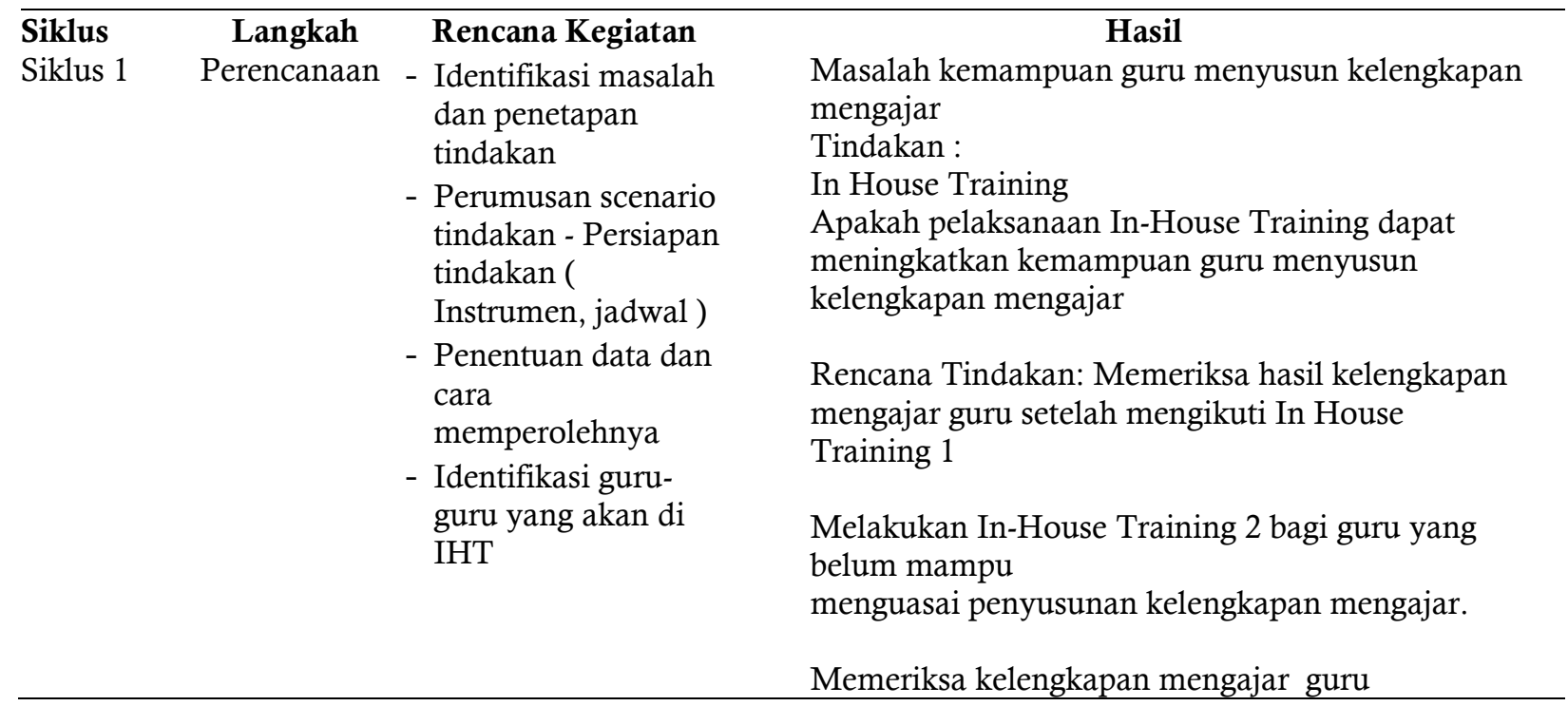


Tabel 2. Rencana Tindakan (Sambungan)

\begin{tabular}{|c|c|c|c|}
\hline \multirow[t]{3}{*}{ Siklus } & $\begin{array}{l}\text { Langkah } \\
\text { Pelaksanaan }\end{array}$ & $\begin{array}{l}\text { Rencana Kegiatan } \\
\text { Tindakan dilakukan sesuai rencana } \\
\text { selama } 2 \text { minggu } \\
\text { Tindakan dilakukan melibatkan semua } \\
\text { guru yang ikut In-House } \\
\text { Training }\end{array}$ & $\begin{array}{l}\text { Hasil } \\
\text { Tindakan dapat dilaksanakan sesuai } \\
\text { scenario }\end{array}$ \\
\hline & Pengamatan & $\begin{array}{l}\text { Pengamatan dilakukan dengan } \\
\text { instrument } \\
\text { Seluruh kejadian dalam proses tindakan } \\
\text { dicatat dalam lembar } \\
\text { observasi }\end{array}$ & $\begin{array}{l}\text { Data kualitatif dengan catatan } \\
\text { peristiwa selama proses tindakan }\end{array}$ \\
\hline & Refleksi & $\begin{array}{l}\text { Evaluasi tindakan dan data-data yang } \\
\text { diperoleh } \\
\text { Pertemuan membahas hasil evaluasi } \\
\text { Merencanakan langkah-langkah siklus } 2\end{array}$ & $\begin{array}{l}\text { Masalah yang dialami } \\
\text { Peristiwa yang terjadi di luar } \\
\text { scenario } \\
\text { Rencana langkahlangkah siklus } 2\end{array}$ \\
\hline \multirow[t]{3}{*}{ Siklus 2} & Perencanaan & $\begin{array}{l}\text { Pelaksanaan In-House Training Tahap } 2 \\
\text { Rencana langkah tindakan sesuai hasil } \\
\text { refleksi } 1\end{array}$ & \\
\hline & Pelaksanaan & Pelaksanaan sesuai skenario siklus 2 & \\
\hline & $\begin{array}{l}\text { Pengamatan } \\
\text { Refleksi }\end{array}$ & $\begin{array}{l}\text { Sesuai rencana siklus } 2 \\
\text { Evaluasi sesuai siklus } 2\end{array}$ & \\
\hline
\end{tabular}

\section{Hasil dan Pembahasan}

\section{Hasil Angket Sebelum In-House Training Dilakukan}

Pentingnya memiliki kelengkapan mengajar Guru UPT SDN 03 Pasar Amping Parak Kecamatan Sutera

Didapat data bahwa 57.4\% Guru menyadari bahwa sebagai seorang Guru sangat penting memiliki kelengkapan mengajar sebelum melaksanakan proses pembelajaran dan $42.6 \%$ menyatakan penting memiliki kelengkapan mengajar. Hal tersebut berarti secara keseluruhan Guru UPT SDN 03 Pasar Amping Parak Kecamatan Sutera menyatakan penting untuk memiliki kelengkapan mengajar.

Hal ini sanghatlah beralasan karena dengan memiliki kelengkapan mengajar yang baik sangat membantu kelancaran dalam proses pembelajaran. Selain itu dengan kelengkapan mengajar akan memberi kesempatan bagi Guru sebagai pendidik untuk merancang pembelajaran sesuai dengan kebutuhan peserta didik, kemampuan peserta didik dan fasilitas yang dimilki sekolah. Demikian pula dengan memiliki kelengkapan mengajar proses pembelajaran yang dilakukan akan lebih terarah, karena tujuan pembelajaran, materi yang akan diajarkan, metode dan penilaian yang digunakan telah dirancang dengan berbagai pertimbangan.

Ketidaksesuaian mata pelajaran yang diajarkan dengan latar belakang pendidikan Guru UPT SDN 03 Pasar Amping Parak Kecamatan Sutera

Diperoleh data bahwa hanya $11.2 \%$ guru yang merasa mata pelajaran yang diajarkan sesuai dengan latar belakang pendidikannya. $44.2 \%$ menyatakan cukup setuju atau ragu-ragu hal ini mungkin Guru merasa mata pelajaran yang diajarkan memang tidak sesuai dengan latar belakang pendidikannya namun mereka merasa mampu mengajarkan mata pelajaran yang diajarkan mungkin karena mata pelajaran yang diajarkan tersebut masih satu rumpun dengan latar belakang pendidikannya. Selebihnya menjawab setuju yang berarti sekitar 44.6\% merasa mengajar tidak sesuai dengan latar belakang pendidikannya. Hal ini terjadi karena UPT SDN 03 Pasar Amping Parak Kecamatan Sutera pada awal berdirinya sangat kesulitan mencari tenaga pengajar sehingga pada waktu itu berlaku pepatah tidak ada rotan akarpun jadi.

\section{Kurangnya Pengalaman Mengajar UPT SDN 03 Pasar Amping Parak Kecamatan Sutera}

Dari tabel tersebut diatas dapat diartikan bahwa $44.4 \%$ menyatakan tidak setuju kalau pengalaman mengajarnya dikatakan kurang, dengan kata lain 44.4\% tersebut Guru merasa sudah berpengalaman dalam mengajar sedangkan sisanya 55.6\% Guru merasa dirinya belum berpengalaman mengajar. Hal ini dikarenakan mungkin mereka belum lama diangkat sebagai Guru 


\title{
Perlunya In-House Training Penyusunan Kelengkapan Mengajar Pada UPT SDN 03 Pasar Amping Parak
} Kecamatan Sutera

Mengindikasikan bahwa hanya $18.0 \%$ saja Guru merasa tidak perlu In-House Trainiing Penyusunan kelengkapan mengajar hal ini terjadi mungkin karena mereka sudah cukup berpengalaman dalam mengajar sehingga tanpa In-House Training mereka merasa sudah bisa menyusun kelengkapan mengajar. 11.6\% menjawab cukup setuju/ragu-ragu mungkin mereka belum mengetahui dengan jelas tentang materi yang akan disampaikan dalam In-House Training sehingga mereka merasa tidak yakin apakah sudah bisa atau belum bisa materi tersebut.

Sedangkan sisanya $70.0 \%$ menyatakan perlu diadakan In-House Training penyusunan kelengkapan mengajar, Dengan demikian dapat dikatakan bahwa sebagian besar Guru UPT SDN 03 Pasar Amping Parak Kecamatan Sutera mengharapkan adanya In-House Training penyusunan kelengkapan mengajar. Hal ini mungkin dikarenakan sebagian besar Guru menyadari bahwa dirinya belum memiliki kelengkapan mengajar dan merasa pengalaman mengajarnya masih kurang serta mata pelajaran yang diajarkan kurang sesuai dengan latar belakang pendidikannya sehingga masih kesulitan dalam menyusun kelengkapan mengajar.

\begin{abstract}
Motivasi Guru dalam Menyusun Kelengkapan Mengajar Pada UPT SDN 03 Pasar Amping Parak Kecamatan Sutera

Di dapat data, 100\% Guru memiliki motivasi yang tinggi untuk mengikuti InHouse Training dan memiliki keinginan yang kuat untuk membuat kelengkapan mengajar bahkan akan menggunakan kelengkapan mengajar tersebut sebagai penunjang proses pembelajaran. Hal ini berarti seluruh Guru UPT SDN 03 Pasar Amping Parak Kecamatan Sutera menyadari pentingnya memiliki kelengkapan mengajar. Dengan demikian In-House Training penyusunan kelengkapan mengajar memang perlu dilakukan dan mendapat dukungan yang kuat dari para Guru. Dengan demikian diharapkan setelah In-House Training dilakukan kemampuan Guru dalam menyusun kelengkapan mengajar akan meningkat.
\end{abstract}

\section{Hasil yang diperoleh pada Siklus 1}

Pada siklus 1 berdasarkan data dari tabel diatas dapat dijelaskan bahwa seluruh Guru sudah mulai menyusun kelengkapan mengajar walaupun belum ada seorangpun Guru yang berhasil menyelesaikan kelengkapan mengajar dengan lengkap namun demikian sudah ada satu orang Guru menyelesaikan $100 \%$, empat orang Guru menyelesaikan $75 \%$ dan yang lainnya masih dibawah $70 \%$ dan yang paling rendah (paling sedikit) berhasil menyusun kelengkapan mengajar adalah sebesar $25 \%$.

Kelengkapan mengajar yang paling banyak terselesaikan pada siklus 1 adalah RPP (Rencana Program Pembelajaran) sebanyak $70 \%$ dan Promes (Program Semester) dan silabus sebesar $40 \%$. Ini berarti ada kecenderungan Guru memulai menyusun kelengkapan mengajar dari siswa yang akan mengikuti UN yaitu siswa kelas VI kemungkinan Guru memprioritaskan siswa yang akan menempuh ujian nasional karena dianggap lebih perlu diperhatikan terutama dalam proses belajar mengajar dibanding kelas bawah karena masih dalam tahap penyesuaian sehingga perlu dirancang terlebih dahulu. Kemungkinan lain ada kecenderungan terbiasa memulai sesuatu dari yang akan lulus

Selain data seperti telah dijelaskan diatas, terdapat satu data yang menggambarkan bahwa ada seorang Guru yang baru menyelesaikan kelengkapan mengajar hanya $25 \%$. Hal ini kemungkinan disebabkan oleh beberapa hal diantaranya, mungkin yang bersangkutan belum lancar menggunakan computer karena dalam mengerjakan tugas tersebut tugas (kelengkapan mengajar) dikumpul dalam bentuk file. Kemungkinan lain yang bersangkutan masih belum begitu paham cara menyusun kelengkapan mengajar tersebut sehingga menjadi lambat dalam mengerjakannya. Atau mungkin juga karena yang bersangkutan tidak meluangkan waktu untuk focus pada penyelesaian tugas tersebut.

Selanjutnya dari tabel terlihat RPP (Rencana Pelaksanaan Pembelajaran) kelas I s/d VI baru mencapai $70 \%$ tersusun oleh Guru. Bahkan ada Guru yang belum menyusun Prota (Program Tahunan) hanya mencapai $40 \%$ kelas I s/d VI dan Promes (Program Semester) untuk mencapai 40\% kelas I s/d VI namun sudah menyusun RPP (Rencana Pelaksanaan Pembelajaran). Hal ini kemungkinan disebabkan karena Guru tersebut menganggap bahwa Prota dan Promes untuk kelas II sama saja dengan Prota dan Promes kelas III sehingga bisa saja disusun belakangan yang penting sudah ada RPPnya

Secara umum, pada siklus 1 sudah seluruh Guru mulai menyusun kelengkapan mengajar (70\% ) namun demikian masih perlu dilakukan tindak lanjut terhadap kegiatan In-House Training tersebut karena indicator keberhasilan In-House Training ini adalah $100 \%$ Guru berhasil menyelesaikan penyusunan kelengkapan mengajar. Setelah dilakukan refleksi terhadap siklus 1 ternyata ada dua hal yang perlu mendapat perhatian sebagai tindak lanjut yaitu: 1) Prosentase Guru yang menyelesaikan kelengkapan mengajar belum mencapai $100 \%$; 2) Kelengkapan mengajar yang telah disusun oleh Guru ternyata masih belum sepenuhnya sesuai 
dengan panduan/pedoman sehingga masih perlu penyempurnaan seperti termuat pada lampiran (tabel refleksi siklus 1$)$.

\section{Hasil yang diperoleh pada Siklus 2}

Pada siklus 2, In-House Training dilakukan untuk menyempurnakan hasil yang diperoleh pada siklus 1 karena setelah dilakukan refleksi ternyata ada dua hal yang perlu ditingkatkan yaitu: 1) Presentase Guru yang menyelesaikan kelengkapan mengajar belum mencapai 100\%; 2) Kelengkapan mengajar yang telah disusun oleh Guru ternyata masih belum sepenuhnya sesuai dengan yang diharapkan yaitu masih perlu penyempurnaan.

Setelah melalui In-House Training tahap 2 yang dilakukan pada tanggal 24 Februari 2020 dan diberi waktu tambahan selama 5 hari untuk menyelesaikan tugas penyusunan kelengkapan mengajar yang terdiri dari Prota (Program Tahunan) Promes (Program Semester), Propem (Program Pembelajaran) dan RPP (Rencana Pelaksanaan Pembelajaran),

Terlihat bahwa telah terjadi peningkatan prosentase Guru yang berhasil menyelesaikan penyusunan kelengkapan mengajar yaitu 42,5\% menjadi 95\%. Dari tabel juga terlihat bahwa seluruh Guru telah meningkat kemampuannya dalam menyusun kelengkapan mengajar hal tersebut dapat dilihat dari prosentase kelengkapan mengajar yang diselesaikan pada siklus 1 dan dibandingkan dengan prosentase kelengkapan mengajar yang diselesaikan pada siklus 2 .

Secara umum seluruh Guru telah terjadi peningkatan kemampuan dalam penyusunan kelengkapan mengajar. Namun seperti data yang terlihat pada tabel 8 di atas masih ada dua orang Guru belum berhasil menyelesaikan keseluruhan kelengkapan mengajar yang ditargetkan. Menurut pengamatan penulis, salah satu dari dua orang Guru tersebut dikarenakan belum menguasai keterampilan komputer sehingga dalam mengerjakan tugas tersebut sangat terhambat. Sedangkan seorang lagi, menurut pengamatan penulis sebenarnya cukup menguasai keterampilan komputer namun yang bersangkutan kebetulan pada saat tugas diberikan ada masalah keluarga sehingga belum sempat menyelesaikan tugas yang diberikan. Tindak lanjut dari siklus 2 adalah: 1) Peserta (Guru) yang belum menguasai keterampilan komputer tersebut dilakukan mentoring dan diberi tambahan waktu untuk menyelesaikan penyusunan kelengkapan mengajar; 2) Peserta yang ada masalah keluarga tersebut diberi kebijakan berupa tambahan waktu untuk menyelesaikan penyusunan kelengkapan mengajar tersebut.

\section{Simpulan}

Berdasarkan hasil penelitian dan data yang dihimpun serta diinterpretasikan oleh penulis, maka dapat disimpulkan sebagai berikut: 1) Secara keseluruhan Guru UPT SDN 03 Pasar Amping Parak Kecamatan Sutera menyatakan penting untuk memiliki kelengkapan mengajar; 2) Sebagian besar Guru UPT SDN 03 Pasar Amping Parak Kecamatan Sutera merasa bahwa pengalaman mengajarnya masih minim pada mata pelajaran yang diajarkan, dan pengetahuan tentang penyusunan kelengkapan mengajar masih kurang; 3) Seluruh Guru UPT SDN 03 Pasar Amping Parak Kecamatan Sutera menghendaki adanya In-House Training penyusunan kelengkapan mengajar; 3) 100\% Guru memiliki motivasi yang tinggi untuk mengikuti In-House Training dan memiliki keinginan yang kuat untuk membuat kelengkapan mengajar dan akan menggunakan kelengkapan mengajar tersebut sebagai penunjang proses pembelajaran. Pada Siklus 1 terdapat 42,5\% Guru berhasil menyelesaikan penyusunan kelengkapan mengajar dan pada Siklus 2 terdapat 95\% Guru berhasil menyelesaikan penyusunan kelengkapan mengajar. Jadi ada peningkatan kemampuan Guru dalam menyusun kelengkapan mengajar sebesar 52,5\%. Untuk meningkatkan kemampuan Guru dalam menyusun kelengkapan mengajat pada UPT SDN 03 Pasar Amping Parak Kecamatan Sutera dapat dilakukan melalui kegiatan InHouse Training.

\section{Referensi}

Rahmat Saripudin. (2008). Peningkatan Mutu Pembelajaran.

Undang-Undang Republik Indonesia Nomor 20 Tahun 2003 tentang Sistem Pendidikan Nasional

Peraturan Pemerintah Republik Indonesia Nomor 19 Tahun 2005 tentang Standar Nasional Pendidikan

Undang-Undang Republik Indonesia Nomor 14 Tahun 2005 tentang Guru dan Dosen

BSNP.(2007).Model Rencana Pelaksanaan Pembelajaran Kurikulum Tingkat Satuan Pendidikan. Jakarta.Depdiknas.

Dadang Dahlan, In-house Training sebagai Sarana Peningkatan Kualitas Guru Tsanawiyah, file.upi.edu/al.php

Dhony Firmansyah,S.Si. (2008). Karya Tulis disampaikan dalam Pelatihan "Sukses Membuat Proposal Penelitian yang Bermutu" Kumiko Education Centre. 